\title{
Інтестинальна мікробіота у пацієнтів із сальмонельозом
}

\section{П.В. Петах}

Державний вищий навчальний заклад «Ужгородський національний університет», Ужгород, Україна

\begin{abstract}
Анотація. Мета: визначити особливості мікробіоти кишечнику (видовий, кількісний склад) при сальмонельозі залежно від віку. Об'єкт і методи дослідження. Відібрано 60 пацієнтів із сальмонельозом за період 2018-2020 рр., яким проведено бактеріологічне дослідження випорожнень. Учасників поділено на дві групи: 1-ша - діти віком <1 року, 2-га - діти віком >1 року та дорослі. Бактеріологічне дослідження випорожнень проводили згідно з діючими наказами та методичними рекомендаціями. Результати. Мікробіота кишечнику пацієнтів 1-ї групи характеризується наявністю Staphylococcus aureus (>104 KУO/г) (47\%), різноманіттям бактерій родин Morganellaceae та Enterobacteriaceae (>104 KУО/г) (82\%) та асоціацією умовно-патогенних бактерій Klebsiella spp. та Proteus spp. (5,8\%). У 58,8\% дітей виявлений кандидоз кишечнику. В усіх осіб 1-ї групи кількість лакто- та біфідобактерій була в межах норми. Жодної дитини без змін видового та кількісного складу мікробіоти кишечнику не виявлено. У 2-й групі кількість осіб із Staphylococcus aureus значно менша (11,6\%). У 27\% осіб виявлено бактерії родин Morganellaceae та Enterobacteriaceae. Candida spp. відмічено у $16 \%$ осіб. Кількість лактобактерій та біфідобактерій в межах норми. 4\% осіб не мали жодних змін видового та кількісного складу мікробіоти кишечнику. Висновки. В обох досліджуваних групах виявлено зміни мікробіоценезу кишечнику різної вираженості. Характерною особливістю пацієнтів 1-ї групи $\epsilon$ наявність Staphylococcus aureus у майже половини дітей та широке різноманіття умовно-патогенних ентеробактерій та бактерій роду Proteus, дріжджоподібних грибів роду Candida. У 2-й групі дисбіотичні процеси менш виражені порівняно з показниками 1-ї групи: утричі менше умовно-патогенних ентеробактерій та бактерій роду Proteus, у 4 рази менше Staphylococcus aureus та у 3,7 раза менше Candida spp.
\end{abstract}

Ключові слова: мікробіота кишечнику, сальмонельоз, дисбактеріоз, кандидоз.

\section{Вступ}

Гострі кишкові інфекції залишаються актуальною патологією, яка потребує постійного удосконалення діагностики, лікування і профілактики. Згідно з даними Всесвітньої організації охорони здоров'я щороку в світі реєструють 68,4-275 млн випадків діарейних захворювань, кількість яких з року в рік збільшується [1].

Доведено вагому роль нормального мікробіоценозу кишечнику у забезпеченні його колонізаційної резистентності, що певною мірою унеможливлює адгезію та колонізацію інших мікроорганізмів, патогенних для людини, у тому числі патогенних ентеробактерій роду Shigella та Salmonella [2].

Лікування гострих кишкових інфекцій, в тому числі сальмонельозу, нерозривно корелює зі станом мікробіоценозу кишечнику, мікрофлора якого $є$ первинною мішенню дії екзогенної флори та факторів ії агресії [3].

у більшості хворих із кишковою інфекцією впродовж перших днів детермінуються дисбіотичні розлади кишечнику різної інтенсивності, під якими насамперед розуміють клініко-лабораторні розлади зі зміною якісного та/або кількісного складу мікрофлори біотопу, транслокацією різних представників у невластиві їм біотопи, розвитком метаболічних та імунних порушень і можливими клінічними симптомами, а також підсиленням розладів травлення з порушенням водноелектролітного обміну, виникненням ентерального синдрому (діарея, здуття живота, бурчання), нерідко - дисфункцію товстого кишечнику, порушення синтезу і засвоєння основних вітамінів, порушення обміну речовин i, як результат, - затяжний перебіг локалізованого гастроінтестинального сальмонельозу [4].

При несвоєчасному зверненні до лікаря чи самолікуванні сальмонельоз може призвести до порушення нормобіоценозу, зниження резистентності організму до інфекційних агентів, що створює умови для підвищення тяжкості перебігу хвороби, виникнення генералізації та носійства сальмонел, саме тому слід визначити основні особливості інтестинальної мікробіоти [5].
Мета дослідження - визначити особливості мікробіоценозу кишечнику у пацієнтів із сальмонельозом у різних вікових групах.

\section{0б'єкт і методи дослідження}

Відібрано 60 пацієнтів із сальмонельозом за період 20182020 рр., яким проведено бактеріологічне дослідження випорожнень. Учасників поділено за віком на дві групи: 1-ша - діти віком $<1$ року $(n=17), 2$-га - діти віком >1 року та дорослі $(n=43)$.

Бактеріологічне дослідження випорожнень проводили згідно 3 діючими наказами та методичними рекомендаціями. Аналізували мікробіоценоз товстого кишечнику за кількістю Escherichia coli (E. coli) (лактозопозитивної, слабоферментуючої, лактозонегативної), Staphylococcus spp., Candida spp., Proteus spp., кількістю гемолітичних форм, умовно-патогенних бактерій родини Enterobacteriaceae, Bifidobacterium spp., Lactobacillus spp.

Для обробки результатів дослідження використовували програму «Excel 2019».

\section{Результати та їх обговорення}

Мікробіота кишечнику пацієнтів 1-ї групи характеризувалася наявністю Staphylococcus aureus (S. aureus) (>104 KУO/г) (47\%), різноманіттям бактерій родин Morganellaceae, Enterobacteriaceae $\left(>10^{4} \mathrm{KYO} / \mathrm{r}\right)$ (82\%), a came: Klebsiella pneumoniae (18,2\%), Enterobacter spp. (47\%), Proteus spp. (5,8\%), Citrobacter (5,8\%) та асоціацією умовно-патогенних бактерій Klebsiella spp. та Proteus spp. (5,8\%). У 58,8\% дітей виявлений кандидоз кишечнику. У 17,7\% пацієнтів відмічали гемолітичну E. coli (>104 KУO/г). Збільшення кількості слабоферментуючої $E$. coli виявлено у 70,5\% пацієнтів. Лактозонегативна E. coli зафіксована у кількості, яка перевищує референсну, в 11\% осіб. Зауважимо, що в усіх пацієнтів 1-ї групи кількість лакто- та біфідобактерій була в межах норми. Жодної дитини без змін видового та кількісного складу мікробіоти кишечнику не виявлено.

У 2-й групі кількість осіб із S. aureus значно менша (11,6\%). у $23,2 \%$ виявлено гемолітичну E. coli. У $27 \%$ осіб виявлено бактерії родин Morganellaceae та Enterobacteriaceae (Klebsiella pneumoniae - 14\%, Enterobacter spp. - 2\%, Citrobacter spp. - 4\%, Proteus spp. - 7\%). Candida spp. відмічено у $16 \%$ осіб. Встановле- 
но підвищення кількості слабоферментуючої E. coli (30\%), лактозонегативної E. coli (14\%); в усіх осіб лактозопозитивна E. coli була в достатній кількості. Кількість лакто- та біфідобактерій - у межах норми. У 4\% осіб не відмічено жодних змін видового та кількісного складу мікробіоти кишечнику.

\section{Висновки}

В обох досліджуваних групах виявлено зміни мікробіоценозу кишечнику різної вираженості. Характерною особливістю пацієнтів 1-ї групи $\epsilon$ наявність S. aureus у майже половини дітей та широке різноманіття умовно-патогенних ентеробактерій та бактерій роду Proteus, дріжджоподібних грибів роду Candida.

У 2-й групі дисбіотичні процеси менш виражені порівняно з показниками 1-ї групи: наявність утричі менше умовно-патогенних ентеробактерій та бактерій роду Proteus, у 4 рази менше S. aureus та у 3,7 раза менше Candida spp.

\section{Список використаної літератури/References:}

1. Porub S.E., Usachova O.V., Paholchuk T.M. (2019) Diarrheal Escherichia coli: features of the clinic and treatment in children of Zaporozhye region. dspace.zsmu.edu.ua/handle/123456789/9819. (In Ukr.).

2. Kramarev S.A., Vygovskaya 0.V. (2008) Probiotics in the clinic of infectious diseases. Perinatology and pediatrics, 1: 140-146. (In Rus.).

3. Sidorchuk A.S., Bogachyk N.A., Venglovska Ya.V. et al. (2013) Gastrointestinal salmonellosis: clinical and epidemiological aspects in Bukovina and modern therapeutic approaches using biolact. Pivdennoukr. Med. Sci. J., 2: 70-72. (In Ukr.).

4. Sukhov Yu.A., Gebesh V.V., Golub A.P. (2008) Influence of enterosorption on the level of antiinflammatory cytokines in intestinal infections and measles. Modern infections, 3: 107-111. (In Ukr.).

5. Maly V.P., Paliy G.K., Paliy D.V., Volyansky Yu.V. (2010) Rationale for anti-infective therapy of salmonellosis. Infectious diseases, 1: 41-46. (In Ukr.).

\section{Intestinal microbiota in patients with salmonellosis}

\section{P.V. Petakh}

Uzhhorod National University, Uzhhorod, Ukraine

Abstract. Objective: to determine the features of the intestinal microbiota (species, quantitative composition) in salmonellosis, depending on age. Materials and methods. 60 patients with salmonellosis (for the period from 2018 to 2020) were selected for bacteriological examination of feces. These patients were divided into two groups: $1^{\text {st }}-$ children $<1$ year of age, $2^{\text {nd }}-$ children $>1$ year of age and adults. Bacteriological examination of feces was performed in accordance with acting orders and methodical recommendations. Results. The intestinal microbiota of children from 1 st group is characterized by the presence of Staphylococcus aureus ( $>10^{4} \mathrm{CFU} / \mathrm{g}$ ) (47\%), a variety of bacteria of the families Morganellaceae and Enterobacteriaceae $\left(>10^{4} \mathrm{CFU} / \mathrm{g}\right)(82 \%)$ and the association conditionally-pathogenic bacteria: Klebsiella spp. with Proteus spp. (5.8\%). Intestinal candidiasis was found in $58.8 \%$ of children. The number of lacto- and bifidumbacteria in all children from $1^{\text {st }}$ group was within normal limits. No child was found without changes in the species and quantitative composition of intestinal microbiota. In $2^{\text {nd }}$ group, the number of patients with Staphylococcus aureus was much lower (11.6\%). Bacteria of the families Morganellaceae and Enterobacteriaceae were found in $27 \%$. Candida spp. was found in $16 \%$. The number of lacto- and bifidumbacteria was within normal limits. $4 \%$ of patients did not have any changes in the species and quantitative composition of intestinal microbiota. Conclusions. It is established that in both studied groups there are changes in the intestinal microbiocenosis of different severity. A characteristic feature of 1st group is the presence of Staphylococcus aureus in almost half of children, a wide variety of conditionally-pathogenic enterobacteria and bacteria of the genus Proteus, yeast-like fungi of the genus Candida. In $2^{\text {nd }}$ group dysbiotic processes are less pronounced, compared to 1st group: the presence of three times less conditionally-pathogenic enterobacteria and bacteria of the genus Proteus, 4 times less - Staphylococcus aureus and 3.7 times less - Candida spp.

Key words: intestinal microbiota, salmonellosis, dysbacteriosis, candidiasis.

\section{Information about the author:}

Petakh Pavlo V. — Assistant Professor, Department of Biochemistry and Pharmacology, Uzhhorod National University, Uzhhorod, Ukraine.

\section{Address for correspondence:}

Pavlo Petakh

88000 , Uzhhorod, Universytets'ka st., 14

E-mail: pavlo.petakh@uzhnu.edu.ua 